\title{
Correction to: Molecular Characterization of Pneumococcal Surface Protein A (PspA), Serotype Distribution and Antibiotic Susceptibility of Streptococcus pneumoniae Strains Isolated from Pakistan
}

Faidad Khan · Jorge E. Vidal · Mohsin Ahmad Khan · Nadeem Ahmed •

Muhammad Islam Khan · Hamid Bashir · Saad Tahir •

Ahmad Usman Zafar

Published online: March 29, 2018

(C) The Author(s) 2018

Correction to: Infect Dis Ther

https://doi.org/10.1007/s40121-018-0195-0

In the original publication, one of the author names was missed in the author group. The correct author group should read as Faidad Khan, Jorge E. Vidal, Mohsin Ahmad Khan, Nadeem Ahmed, Muhammad Islam Khan, Hamid Bashir, Saad Tahir, Ahmad Usman Zafar.

Jorge E. Vidal's affiliation is: Hubert Department of Global Health, Rollin's School of Public Health, Emory University, Atlanta, GA, USA.

Disclosures: Faidad Khan, Jorge E. Vidal, Mohsin Ahmad Khan, Nadeem Ahmed, Muhammad Islam Khan, Hamid Bashir, Saad Tahir and
Ahmad Usman Zafar having nothing to disclose.

Open Access. This article is distributed under the terms of the Creative Commons Attribution-NonCommercial 4.0 International License (http://creativecommons.org/licenses/ by-nc/4.0/), which permits any noncommercial use, distribution, and reproduction in any medium, provided you give appropriate credit to the original author(s) and the source, provide a link to the Creative Commons license, and indicate if changes were made.

The original article can be found online at https://doi. org/10.1007/s40121-018-0195-0.

F. Khan $(\bowtie) \cdot$ M. A. Khan · N. Ahmed .

M. I. Khan - H. Bashir - S. Tahir - A. U. Zafar

Centre of Excellence in Molecular Biology,

University of the Punjab, Lahore, Pakistan

e-mail: faidadkhan@cemb.edu.pk

J. E. Vidal

Hubert Department of Global Health, Rollin's

School of Public Health, Emory University, Atlanta,

GA, USA 